Nat. Hazards Earth Syst. Sci., 18, 257-269, 2018

https://doi.org/10.5194/nhess-18-257-2018

(C) Author(s) 2018. This work is distributed under the Creative Commons Attribution 3.0 License.

\title{
Assessing the impact of Syrian refugees on earthquake fatality estimations in southeast Turkey
}

\author{
Bradley Wilson and Thomas Paradise \\ Department of Geosciences, University of Arkansas, Fayetteville, Arkansas, USA
}

Correspondence: Bradley Wilson (bsw006@uark.edu)

Received: 10 February 2017 - Discussion started: 13 March 2017

Revised: 22 October 2017 - Accepted: 28 November 2017 - Published: 19 January 2018

\begin{abstract}
The influx of millions of Syrian refugees into Turkey has rapidly changed the population distribution along the Dead Sea Rift and East Anatolian fault zones. In contrast to other countries in the Middle East where refugees are accommodated in camp environments, the majority of displaced individuals in Turkey are integrated into local cities, towns, and villages - placing stress on urban settings and increasing potential exposure to strong earthquake shaking. Yet displaced populations are often unaccounted for in the census-based population models used in earthquake fatality estimations. This study creates a minimally modeled refugee gridded population model and analyzes its impact on semi-empirical fatality estimations across southeast Turkey. Daytime and nighttime fatality estimates were produced for five fault segments at earthquake magnitudes 5.8, 6.4, and 7.0. Baseline fatality estimates calculated from census-based population estimates for the study area varied in scale from tens to thousands of fatalities, with higher death totals in nighttime scenarios. Refugee fatality estimations were analyzed across 500 semi-random building occupancy distributions. Median fatality estimates for refugee populations added non-negligible contributions to earthquake fatalities at four of five fault locations, increasing total fatality estimates by $7-27 \%$. These findings communicate the necessity of incorporating refugee statistics into earthquake fatality estimations in southeast Turkey and the ongoing importance of placing environmental hazards in their appropriate regional and temporal context.
\end{abstract}

\section{Introduction}

Since Syria's devolution into Civil War in early 2011, millions of Syrians have fled into Turkey seeking reprieve from areas of territorial conflict. As of December 2016, the refugee population in Turkey is nearing 2.8 million, with the majority of the population located in southeastern provinces (Republic of Turkey, 2015). This influx of population has rapidly changed the population distribution of earthquake-prone areas near the East Anatolian and Dead Sea Rift fault systems, increasing the number of individuals potentially exposed to strong earthquake shaking.

The refugee crisis in Turkey is unique in several ways that are relevant to earthquake risks. In contrast to other countries in the Middle East, the majority of Syrian refugees in Turkey are settled amongst local populations rather than formalized refugee camps. This implies a form of temporary urbanization - 3RP (2015) notes that an increased volume of refugees is stressing to local cities seeking to adequately accommodate increased populations. This distinction also complicates the process of accounting for refugees in population models. Refugees in Turkey have to be modeled across large geographic areas rather than simply including refugee camp populations.

Increased building occupancy raises the potential for earthquake disasters in southeast Turkey, especially given the country's poor historical precedent for earthquake mitigation. There are clear relationships between urbanization, building code enforcement, and earthquake fatalities in Turkey. The lack of seismic building code enforcement is an ongoing problem and has been linked to high rates of urbanization in the past (Erdik, 2001). This is particularly problematic in light of clear relationships between earthquake fatalities and building collapse (Oskai and Minowa, 2001; 
Nadim et al., 2004; Coburn and Spence, 2002), and major concerns over the structural integrity of existing building stock (Ilki and Celep, 2012). Poor code enforcement has been mentioned as a contributing factor to high death tolls in recent Turkish earthquakes (Erdik, 2001; Güney, 2012). This particular issue, however, extends beyond Turkey. The lack of building code enforcement is a major contributing factor to elevated earthquake mortality rates across the developing world. Earthquake-resistant structures are both expensive to construct and time consuming to license and verify. This creates opportunities for corrupt payments, bribes, and a lack of political incentives to diminish enforcement of building codes (Keefer et al., 2011; Anbarci et al., 2005).

Structural vulnerability is intertwined with population exposure in earthquake risk analyses. Accurately mapping population exposure is an essential part of the risk analysis process for environmental hazards (Chen et al., 2004; Freire and Aubrecht, 2012; Aubrecht et al., 2012). The presence of Syrian refugees in southeast Turkey complicates this process, especially as it pertains to datasets commonly used in earthquake fatality estimations. Displaced Syrian populations are tracked at varying levels by the Turkish government and international agencies but are difficult to model at high resolution. Refugees are registered at the province level but are afforded freedom of movement within their registered province under the Temporary Protection Regulations, the legal framework for refugees in Turkey (Çorabatır, 2016). Thus, the position of refugees within any designation smaller than provinces - district, city, or village - is uncertain. These uncertainties present challenges for earthquake loss estimations that rely on accurate population estimates.

Improved human exposure data impact several components of the risk analysis process, including loss estimation and disaster relief (Chen et al., 2004; Aubrecht et al., 2012; Guha-Sapir and Vos, 2011). Studies by Aubrecht et al. (2012) and Ara (2014) have shown the paramount importance of incorporating temporal factors into population datasets. Despite these findings, most earthquake-related hazard studies do not account for temporal population changes and instead rely on census-based population estimates (Freire and Aubrecht, 2012). In the absence of building level data on structural type and time-varying occupancy (which are often nonexistent, especially in developing nations), fatality estimations utilize census data or modified versions of census data - either disaggregated by uniformly distributing population over areal units or converted into a finer-resolution dasymetric model using a variety of geographical constraints.

Fatality estimation tools play an important role in both mitigation and relief and recovery processes. Earthquake rapid-response systems have shown promise in accurately characterizing earthquake impacts for emergency management purposes (Wyss, 2004; Erdik et al., 2011; van Stiphout et al., 2010). However, the accuracy of input data in developing nations remains a major concern (Wyss, 2004). In Turkey, refugee populations are not accounted for in the census data due to recency - the last census was completed in 2011, the same year of the Syrian crisis' onset. Therefore, any product produced using census-based population sources is likely to underestimate population exposure unless explicitly adjusted for Syrian populations.

This study addresses this challenge by (1) minimally modeling refugee population statistics with Turkish population estimates into a series of gridded population datasets and (2) assessing the corresponding impact on earthquake fatality estimations at five geographically distributed fault segments across southeast Turkey. Using the semi-empirical loss estimation technique of Jaiswal and Wald (2010), fatality estimates are simulated for a range of earthquake magnitudes. By evaluating the relative contribution of refugee populations within total fatality estimates, the degree to which censusbased approaches underestimate fatalities is shown. These results communicate the importance of incorporating refugee populations into natural-hazard risk assessments.

\section{Study area}

As of December 2016, there were 2790767 registered Syrian refugees in Turkey, over half of the Syrian conflict's total refugees and more than any other country in the Middle East. Turkey currently has 23 refugee camps operating at full capacity across 10 provinces, accommodating approximately $10 \%$ of the total registered population. The remaining $\sim 90 \%$ of refugees are settled amongst local communities in their provinces of registration. This comes in stark contrast to other countries in the Middle East where a majority of refugees are housed in camped environments. The Turkish Ministry of the Interior Directorate General of Migration Management (DGMM) consistently updates these statistics as more Syrians are formally registered as refugees within the country.

A majority $(\sim 60 \%)$ of Syrian refugees have settled in southeastern provinces near the Turkey-Syria border, with the highest concentrations located in provinces bordering Syria directly (Fig. 2). The area of focus for this study encompasses 12 primary southeastern provinces and portions of three additional provinces. This region extends from the northwest corner of Kayseri to the southeast corner of Şanliurfa (Fig. 1). Tectonically, this region is dominated by two primary left-lateral strike-slip fault systems, the East Anatolian fault zone and the Dead Sea Rift fault zone, which bound the intersection between the relatively stable Arabian platform and the Anatolide-Tauride block. The precise structural relationship between these two fault systems is complex and poorly understood. Their intersection is generally placed at a triple junction near the city of Kahramanmaraş (Chorowicz et al., 1994), or slightly further south near Antakya (Over et al., 2004). Various explanations for the mechanics of the two systems have been explored in Perinçek and Çemen (1990) and Duman and Emre (2013). Under ei- 


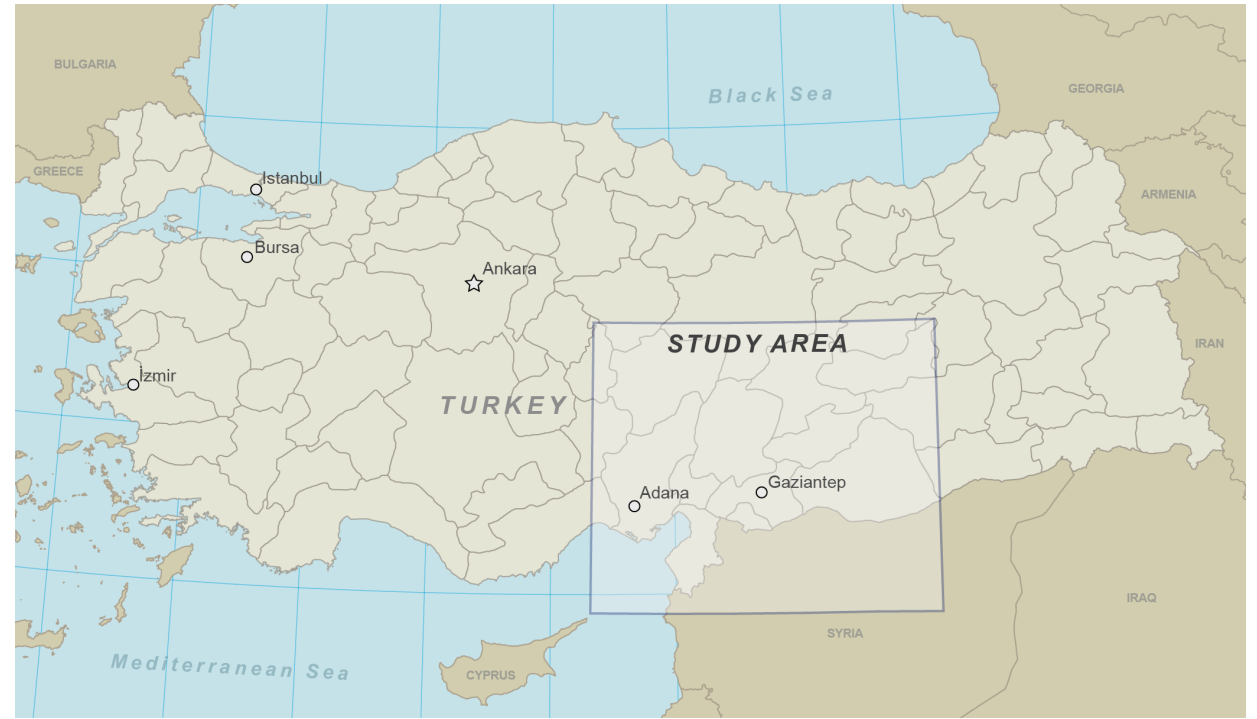

Figure 1. Study area within southeastern Turkey.

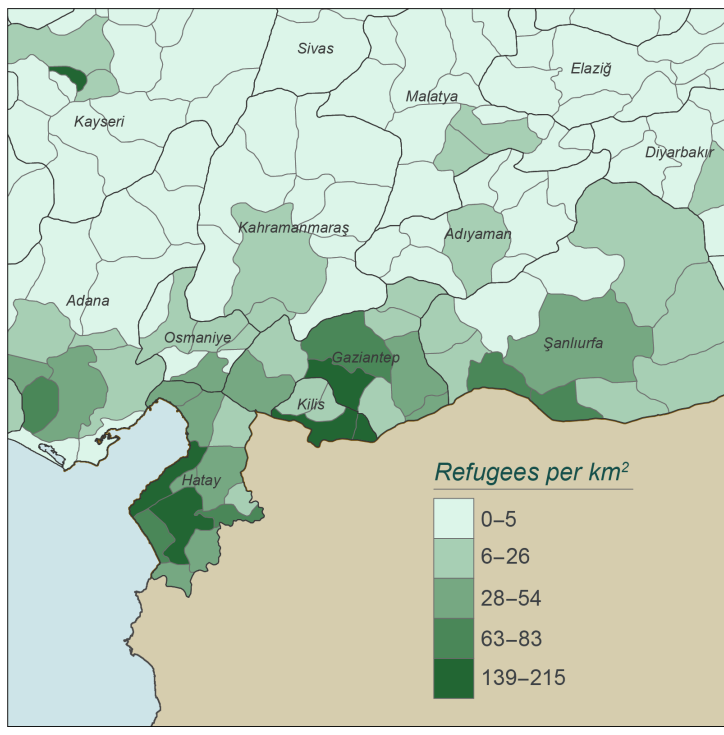

Figure 2. Migrated population density, December 2016.

ther explanation, refugee settlement in southeastern Turkey represents a migration away from a stable tectonic setting into an area characterized by frequent earthquake activity.

\section{Historical seismicity}

There is a robust record of earthquake activity earthquake activity in the East Anatolian and Dead Sea Rift fault systems (Ambraseys, 2009; Sbeinati et al., 2005; Barka and Kadinsky-Cade, 1988; Garfunkel et al., 1981). Ambraseys (2009) provides a detailed overview of historical seismicity in the region, with Sbeinati et al. (2005) providing additional information on Syrian earthquakes. Both the East Anatolian and Dead Sea Rift fault systems have seen a recent quiescence in seismic activity, but paleoseismic evidence indicates a consistent long-term pattern of infrequent large earthquakes (Ambraseys, 1989; Meghraoui et al., 2003). Figure 3 plots seismic activity greater than magnitude 5.0 across the study area over the last millennia, showing a fairly even distribution across the length of the fault zones.

Historical records also provide insight into the human impact of several notable earthquakes. The earthquakes that destroyed the city of Antioch (located in the Hatay province of modern day Turkey) in $115 \mathrm{CE}$ and $526 \mathrm{CE}$ are estimated to have killed 250000 or more individuals each. If these numbers are correct, both earthquakes fall into the top 10 most deadly earthquakes of all time (Musson, 2001) (the death estimates may be exaggerated but are generally considered to be plausible; Ambraseys, 2009). The 526 CE earthquake is particularly notable, striking on 29 May, Ascension Day. Ambraseys (2009) mentions that the influx of visitors into the city likely amplified fatalities.

\section{Data and methods}

\subsection{Refugee-inclusive population model}

The last Turkish census was completed in 2011 before the onset of Syrian mass migration. Therefore, most population models built from census-based sources do not account for the presences of Syrian refugees. This is not an intentional error (Gridded Population of the World version 4 dataset (GPWv4; Doxsey-Whitfield et al., 2015) explicitly states this particular shortcoming) but rather a systematic problem associated with infrequent data collection. Any forward-modeled 


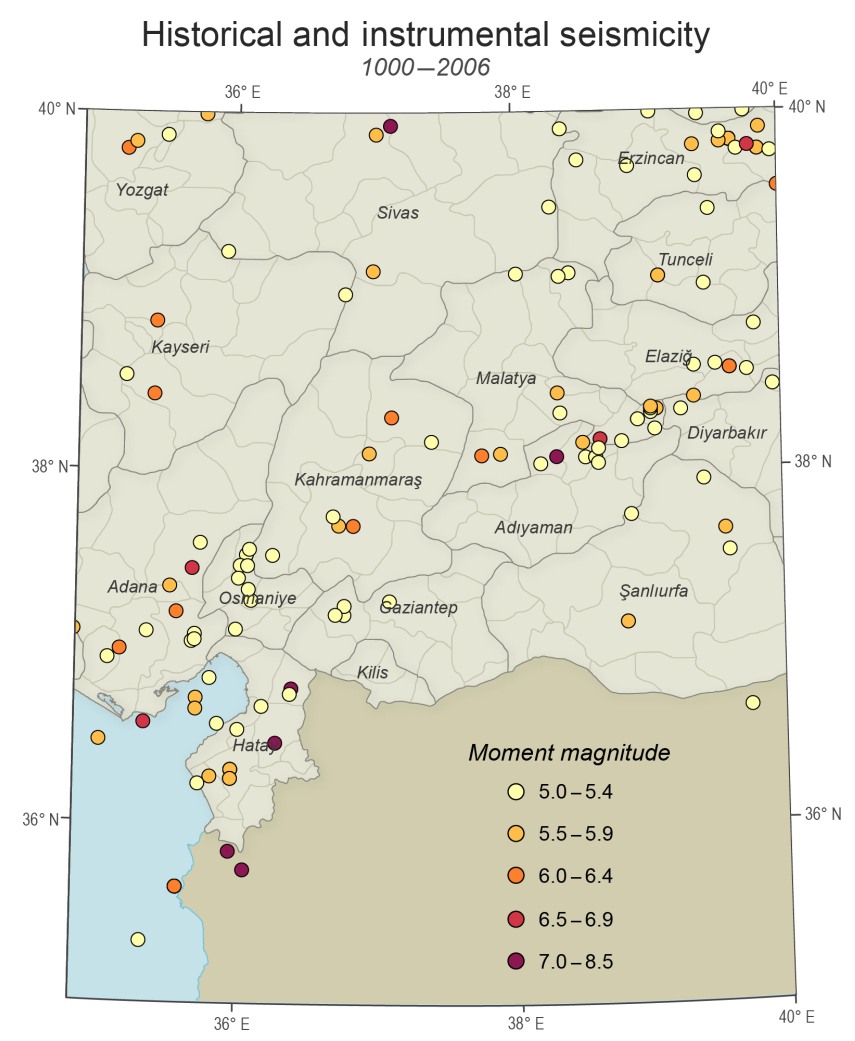

Figure 3. The distribution of earthquake shaking as gathered from historical documents and modern seismic networks, compiled in Sesetyan et al. (2013).

population dataset for Turkey based on pre-2011 data will mischaracterize true populations unless refugees are explicitly included. Population models that incorporate migration at some level do exist, most notably Oak Ridge National Laboratory's LandScan $^{\text {TM }}$ database (ORNL, 2016), but they remain proprietary products.

As a framework for modifying regional census data for inter-period migration events, a geographic information systems (GIS) workflow was utilized to construct a regional refugee-inclusive gridded population model using freely available data from Turkey's Address Based Population Registration System (ABPRS) and the Turkish DGMM. The DGMM, part of the Turkish Department of the Interior, is responsible for regularly disseminating registered refugee population statistics. These statistics are widely used in refugeerelated reporting by the European Commission, United Nations High Commissioner for Refugees, and the US Humanitarian Information Unit, among others.

The framework for this study employs a minimally modeled areal distribution process that disaggregates administrative population counts into cells of equal population. Turkish district level boundaries from the GADM database of Global Administrative Areas (GAA, 2015), clipped to the area of interest, were first converted into $3 \mathrm{~km}$ grid cells and equally distributed 2015 ABPRS populations according to the pro- portional number of cells in each district. Refugee migration data are monitored at the province level, one administrative boundary larger than the ABPRS estimates. As mentioned above, the exact position of non-camped Syrian refugees within their respective provinces is unknown. Accordingly, the existing district level population distribution was used as a proxy for refugee settlement patterns. The non-camped refugee population was distributed according to the relative percentages between district and province level populations. Camped refugee populations were assigned to the district corresponding to the camp location and removed from the populations otherwise distributed. The model was finalized by repeating the process used above for distributing ABPRS populations to allocate refugees into equally populated grid cells. The resulting gridded population model (Fig. 4) is spatially consistent and has discrete values for base population and registered refugee population.

\section{Advantages and drawbacks}

In contrast to other areal gridded population models, this study explicitly accounts for registered refugee populations. The methods used to incorporate temporary populations are straightforward to replicate and update as the DGMM releases new registration statistics. It should be noted, however, that refugees and displaced persons are not equivalent designations. The DGMM statistics used in this study only include registered refugee populations and may not capture the full number of displaced Syrians living in Turkey. Other fatality estimation studies, particularly those with larger study areas, may prefer a globally gridded model (like the GPWv4 dataset). Alternatively, proprietary gridded population models are also an option. LandScan ${ }^{\mathrm{TM}}$ is updated yearly and may provide improved characterization of refugee settlement, but its dasymetric mapping techniques are not open source.

The primary drawback to the methodology used in this study is the assumption that refugees and local populations are distributed equally at the sub-province level throughout the study area. It is probable that actual refugee populations exhibit different spatial clustering. However, refugees are allowed freedom of movement within their province of registration (Çorabatır, 2016), making it difficult to specify an alternative distribution without any additional constraining information. Using equal district level distributions, with camp locations taken into account, at minimum maintains the regional urban-rural distribution - an important classification for fatality estimations.

\subsection{Earthquake scenarios}

Earthquake scenarios are an important tool for emergency management planning. Tools like the USGS' Prompt Assessment of Global Earthquake Risk (PAGER) system and the Federal Emergency Management Agency's (FEMA) HAZUS software have been used in the US for emergency 
(a) ABPRS population model

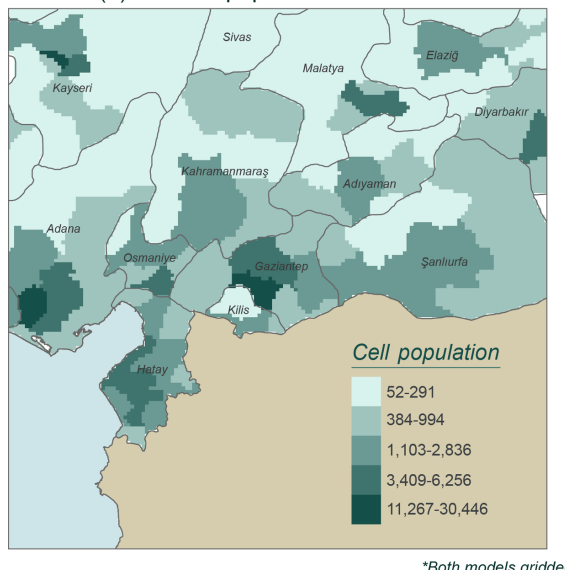

(b) Refugee adjusted ABPRS population model

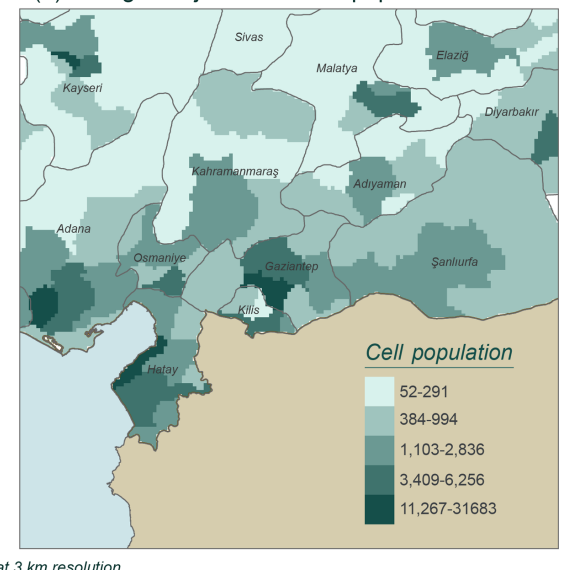

Figure 4. Gridded cellular population models produced from Turkish ABPRS data before (a) and after (b) including refugee statistics.

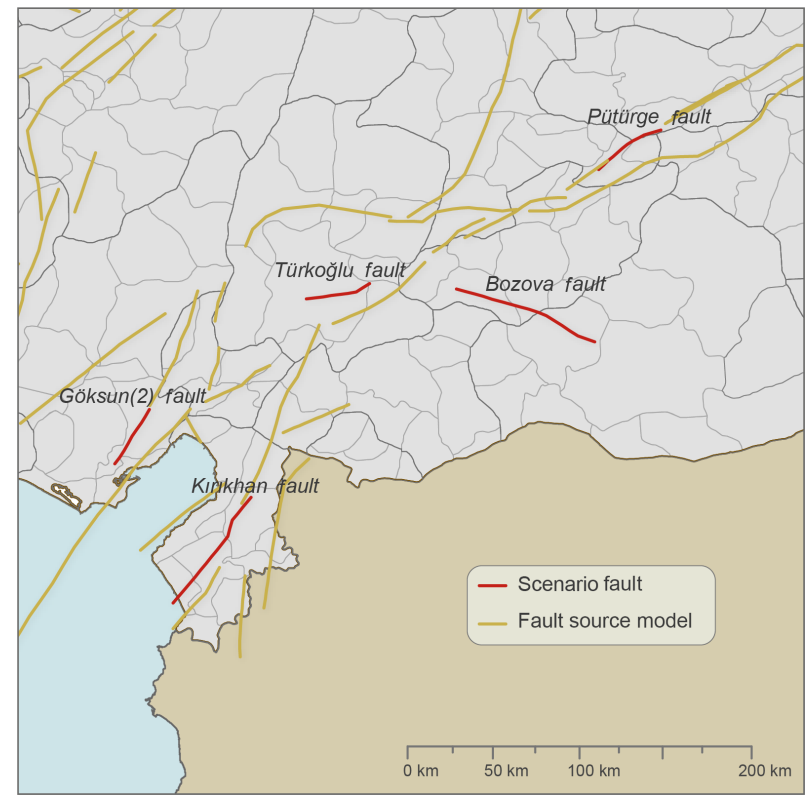

Figure 5. Fault locations selected for earthquake scenarios.

planning at both the national and state level (FEMA, 2008; Chen et al., 2016; EERI, 2015). As part of the earthquake fatality estimation process, synthetic ground motion fields were produced for a series of earthquake ruptures spanning five faults across southeastern Turkey. For each fault, moment magnitude 5.8, 6.4, and 7.0 earthquakes were simulated. This spread of earthquake magnitudes reflects moderate to major earthquakes within the magnitude range of historical earthquakes in the area as seen in earthquake catalogs covering Turkey (Zare et al., 2014; Woessner et al., 2015). Five earthquake epicentral locations were selected along fault traces provided in the fault-source background model in the Seismic Hazard Harmonization of Europe (SHARE) project. It should be noted that the choice of exact epicen-
Table 1. Earthquake rupture input parameters.

\begin{tabular}{lrrrr}
\hline $\begin{array}{l}\text { Fault } \\
\text { name }\end{array}$ & $\begin{array}{r}\text { Hypocenter } \\
\text { (Lon, Lat) }\end{array}$ & Depth & Dip & Rake \\
\hline Pütürge & $(38.20,37.77)$ & 13.2 & 70.0 & 0.0 \\
Kırıkhan & $(36.08,36.27)$ & 13.2 & 80.0 & 0.0 \\
Türkoğlu & $(37.48,37.04)$ & 13.2 & 80.0 & 0.0 \\
Göksun & $(37.03,35.77)$ & 13.2 & 80.0 & 0.0 \\
Bozova & $(37.32,38.59)$ & 13.2 & 80.0 & 180.0 \\
\hline
\end{tabular}

Upper and lower boundaries of the seismogenic layer were set to 0 and $20 \mathrm{~km}$, respectively.

tral location is somewhat arbitrary but can have an impact on fatality levels. Epicenters for this study were selected to represent geographically distributed fault segments and were chosen independently of refugee migration patterns.

The Global Earthquake Model's OpenQuake software platform was utilized to produce ground motion fields for each earthquake scenario. OpenQuake's scenario-based hazard assessment implements ground motion prediction equations to estimate the geographic distribution of shaking intensity for a user-specified fault rupture (GEM, 2016). An overview of rupture input parameters for each fault segment used in this study is available in Table 1. For each scenario, OpenQuake generates the rupture area internally from magnitude and rake using the area-magnitude scaling relationship defined in Wells and Coppersmith (1994). The rupture area is allowed to float along its corresponding fault trace (Fig. 5). All of the scenarios in this study utilized the ground motion prediction equation detailed in Akkar and Bommer (2010), relevant to earthquakes in Europe and the Middle East. Site amplification was accounted for by using Vs30 estimates from the USGS Global Vs30 Map server, which estimates Vs30 from topographic slope (Wald and Allen, 2007). OpenQuake implements site parameters by assigning each observation grid cell the site parameters of the nearest mea- 
Table 2. Collapse rates and fatality rates by structural type.

\begin{tabular}{llrrrrr}
\hline & & \multicolumn{5}{c}{ Collapse \% by intensity } \\
\cline { 3 - 5 } Structural class & WHE-PAGER type & VI & VII & VIII & IX & FR (\%) \\
\hline \multirow{2}{*}{ Masonry } & DS & 0 & 1 & 14 & 45 & 8 \\
& A & 2 & 17 & 48 & 90 & 6 \\
& UFB & 0 & 3 & 18 & 43 & 6 \\
& UCB & 0 & 0 & 3 & 10 & 8 \\
\hline \multirow{2}{*}{ Structural concrete } & C2 & 0 & 0 & 0 & 2 & 15 \\
& C3 & 0 & 0 & 2 & 11 & 15 \\
& C6 & 0 & 1 & 5 & 15 & 15 \\
& C7 & 0 & 2 & 22 & 45 & 15 \\
& PC2 & 0 & 1 & 6 & 15 & 15 \\
\hline Steel & S1 & 0 & 0 & 0 & 1 & 14 \\
\hline Wood & W & 0 & 2 & 10 & 20 & 13 \\
\hline
\end{tabular}

Collapse rates are rounded to the nearest percent.

surement in the Vs30 grid (GEM, 2016). For each earthquake scenario, 10 ground motion fields were produced - each resampling the aleatory uncertainty in the ground motion prediction equation.

\subsection{Fatality estimations}

There are a variety of methods for estimating earthquake fatalities. Jaiswal et al. (2011b) specifies three primary categories: empirical, analytical, and hybrid approaches. The three categories differ in their input data. Empirical methods derive fatality rates from historical records, analytical methods use detailed structural engineering and building occupancy information, and hybrid (semi-empirical) approaches use empirical estimates of building collapse rates and occupancy. The choice of methodology is usually dictated by data availability and the scale of analysis (Jaiswal et al., 2011b).

In this study, a semi-empirical methodology was used to estimate fatalities in earthquake scenarios. Empirical approaches were deemed poorly suited to this particular problem because fatality rates are derived from numerous historical earthquake events. This study is based on the concept that earthquakes in the short term will have higher fatalities due to contextual population increases. Analytical approaches, while the most robust of the three methods, also have the highest data requirements. The structural performance and building occupancy data necessary to support an analytic approach are not available for Turkey, even before considering the challenges of including refugee populations. Accordingly, this study employs the semi-empirical approach detailed in Jaiswal and Wald (2010), given by Eq. (1).
$E[L] \approx \sum_{i=1}^{n} \sum_{j=1}^{m} P_{i} \times f_{i j} \times \mathrm{CR}_{j}\left(S_{i}\right) \times \mathrm{FR}_{j}$

This approach estimates fatalities given a series of $n$ grid cells and $m$ structural types. Each grid cell's population $P_{i}$ is first broken out into a fractional percentage for a given structural type $f_{i j}$. Fatalities are then calculated based on the collapse rate of structural type $j\left(\mathrm{CR}_{j}\left(S_{i}\right)\right)$ at macroseismic intensity $\left(S_{i}\right)$ and the fatality rate $\mathrm{FR}_{j}$ of structure type $j$ under collapse (Jaiswal and Wald, 2010).

Empirical data from the World Housing Encyclopedia (WHE)-PAGER project, phase I, were used to constrain collapse rates. Jaiswal and Wald (2009b) provides estimates of the building stock distribution under the PAGER taxonomy along with estimated collapse percentages. It is noted that several of the collapse probabilities in Jaiswal and Wald (2009b) are higher than estimates that have been generalized across the entire WHE-PAGER phase I dataset (Jaiswal et al., 2011a). Accordingly, when available, collapse rates were calculated using generalized fragility coefficients (listed in Appendix A) using Eq. (2). For building types without published coefficients, values were estimated using the methodology in Jaiswal and Wald (2010), minimizing the residual error of the power function in Eq. (2) fit to a single set of collapse rates at given intensities. Fatality rates were drawn from Jaiswal and Wald (2010) for building types with HAZUS-MH fatality rates and generalized Turkish values from Porter et al. (2008) in their absence.

$\mathrm{CR}_{j}(S)=A_{j} \times 10^{\frac{B_{j}}{S-C_{j}}}$ 
Table 3. Building occupancy percentages by structural type and time of day, from Jaiswal and Wald (2009b).

\begin{tabular}{llrrrr}
\hline Structural class & $\begin{array}{l}\text { WHE-PAGER } \\
\text { type }\end{array}$ & $\begin{array}{r}\text { Urban } \\
\text { daytime }\end{array}$ & $\begin{array}{r}\text { Urban } \\
\text { nighttime }\end{array}$ & $\begin{array}{r}\text { Rural } \\
\text { daytime }\end{array}$ & $\begin{array}{r}\text { Rural } \\
\text { nighttime }\end{array}$ \\
\hline Masonry & DS & 4 & 15 & 0 & 1 \\
& A & 2 & 15 & 0 & 2 \\
& UFB & 25 & 35 & 15 & 35 \\
& UCB & 5 & 5 & 15 & 25 \\
\hline \multirow{2}{*}{ Structural concrete } & C2 & 5 & 0 & 5 & 0 \\
& C3 & 40 & 25 & 50 & 36 \\
& C6 & 5 & 0 & 6 & 0 \\
& C7 & 8 & 0 & 5 & 0 \\
& PC2 & 2 & 0 & 2 & 1 \\
\hline Steel & S1 & 0 & 0 & 1 & 0 \\
\hline Wood & W & 4 & 10 & 1 & 1 \\
\hline
\end{tabular}

Daytime refers to working hour percentages, nighttime to living hour percentages.

\section{Implementation}

All fatality estimations were calculated using R statistical software. Peak ground acceleration (PGA) values for each earthquake scenario were converted to modified Mercalli intensity values using the relationship specified in Wald et al. (1999) and spatially joined to both refugee and non-refugee populations. For each scenario, fatality estimations were first calculated for non-refugee populations. At each grid cell, populations were fractionally divided into building types using the occupancy distributions shown in Table 3 and an urban-rural classification of 150 persons per kilometer (based on the definition in OECD, 1994). Collapse and fatality percentages for each building typology $\left(\mathrm{CR}_{j}\left(S_{i}\right)\right.$ and $\mathrm{FR}_{j}$ ) were drawn from Table 2. The same framework was applied to refugee populations, but several adjustments were made to account for increased uncertainty in the housing situation of refugees. Instead of using the occupancy percentages in Table 3 (which represent expert estimates for local populations), refugee populations were distributed into 500 semi-random occupancy tables. All other parameters (collapse rates, fatality rates, urban-rural classifications) remained the same. Total scenario level fatality estimates were then finalized by summing median refugee fatality estimates with non-refugee fatalities.

Refugee occupancy tables were generated by sampling normal random-number generators. Unique generators were created for every building type in all population distribution scenarios (urban day, urban night, rural day, rural night). The normal distributions for each generator were based on the information in Table 3: means were set to the existing occupancy percentages and standard deviations were set to the calculated standard distribution for each population distribution scenario. This approach was chosen over manual specification or fully random percentage generation for several reasons. First, it is probable that the building distribution of refugees is loosely similar to that of local populations, given the implicit understanding that the available building stock in a given region is largely fixed. Secondly, determining the central tendency and variance of refugee fatalities across hundreds of occupancy tables provides a reasonable way to characterize occupancy-related fatality variations in the absence of further information.

\section{Results and discussion}

Fatality estimates for 15 earthquake scenarios were calculated for this study, covering three earthquake magnitudes in five fault zones in southeastern Turkey. For each earthquake scenario, fatality estimates were produced for non-refugee and refugee populations in both daytime and nighttime building occupancy distributions. Tables 4 and 5 present fatality estimates for all 15 earthquake scenarios. Table 4 shows baseline fatality estimates produced using the gridded population model without incorporating Syrian refugees. Table 5 shows the median fatality estimates and median absolute deviations resulting from the refugee population model.

\subsection{Interpreting fatality estimates}

The results presented in Tables 4 and 5 were transferred directly from fatality calculations without applying any rounding. Non-rounded values were included to allow for closer comparisons to be drawn between individual scenarios. However, this choice may inadvertently suggest that the values presented are very precise - this is not the case. Every attempt has been made to utilize the best data available, but semi-empirical fatality estimations remain a fundamentally uncertain process and will not be perfectly accurate. Yet there is ample evidence to suggest that fatality estimations 
Table 4. Fatality estimates for non-refugee populations.

\begin{tabular}{lrrr}
\hline Fault & $M_{\mathrm{W}}$ & $\begin{array}{r}\text { Daytime } \\
\text { fatalities }\end{array}$ & $\begin{array}{r}\text { Nighttime } \\
\text { fatalities }\end{array}$ \\
\hline Pütürge & 5.8 & 27 & 62 \\
& 6.4 & 91 & 178 \\
& 7.0 & 202 & 372 \\
\hline Türkoğlu & 5.8 & 430 & 657 \\
& 6.4 & 945 & 1380 \\
& 7.0 & 1514 & 2187 \\
\hline Kırıkhan & 5.8 & 1268 & 1886 \\
& 6.4 & 2832 & 3991 \\
& 7.0 & 4461 & 6144 \\
\hline Göksun & 5.8 & 773 & 1119 \\
& 6.4 & 1712 & 2402 \\
& 7.0 & 2944 & 4099 \\
\hline Bozova & 5.8 & 646 & 980 \\
& 6.4 & 1335 & 1942 \\
& 7.0 & 2111 & 3055 \\
\hline
\end{tabular}

remain a useful procedure for determining disaster scale and response capacity needs (Wyss, 2004; Erdik et al., 2011; Jaiswal et al., 2011b). The US Geological Survey provides the following estimates for response levels at varying earthquake fatality thresholds:

- 1-100 fatalities: regional response required;

- 100-1000 fatalities: national response required;

- 1000+ fatalities: international response required.

It is also stressed that the values shown in Tables 4 and 5 do not represent fatality predictions for future earthquakes. Rather, the fatality estimates are better interpreted as orderof-magnitude estimates for hypothetical earthquakes of varying size and location. Therefore, the conclusions drawn henceforth are scenario specific - they should only be generalized to other scenarios with appropriate caution.

\subsection{Baseline fatality estimates}

Fatality estimations were first produced for non-refugee populations to provide baseline values. These baseline values, shown in Table 4, help determine how earthquake fatalities in southern Turkey vary with earthquake magnitude, location, and time of day. At all five fault locations, increasing earthquake magnitudes from 5.8 to 6.4 corresponded with larger fatality increases ( $241 \%$ on average) than subsequent increases when magnitudes were changed from 6.4 to 7.0 ( $175 \%$ on average). These results are expected given the logarithmic relationship between magnitude and intensity.

Nighttime fatalities were estimated higher than daytime fatalities at all fault locations (an average of $160 \%$ ). This indicates that the building stock distribution occupied during working hours is less susceptible to collapse than the building stock distribution occupied during nighttime hours. These results are supported by the occupancy patterns seen in Table 3, which shows that populations generally transition from vulnerable masonry buildings at night to concrete structures during working hours. Additionally, it is probable that the percentage of populations located outdoors is higher during working hours than during nighttime hours, especially in rural environments. These findings add to the growing volume of research stressing the importance of including temporal elements into natural-hazard studies (Chen et al., 2004; Ara, 2014; Aubrecht et al., 2012; Freire and Aubrecht, 2012; Guha-Sapir and Vos, 2011).

Every earthquake scenario included in this study produces casualties that would require at minimum regional response. Many of the scenarios, especially at earthquake magnitudes 6.4 and higher, would likely require national or international response. These results indicate consistently high levels of seismic risk across most of southeast Turkey - a region with a deep history of deadly earthquake activity (Ambraseys, 2009). The differences in fatality estimates between fault locations register the relative proximity of each fault segment to areas with high populations. The two fault segments with the highest fatality estimates, Kırıkhan and Göksun, are both located within some of the highest-population districts across southeast Turkey.

\subsection{Refugee fatalities}

Median fatality estimates and median absolute deviations based on 500 building occupancy iterations are shown in Table 5 . The median absolute deviations of refugee fatality estimations, based on adjustments in building occupancy percentages, range from 25 to $55 \%$ of median estimates. These variations may have implications for the severity of a particular earthquake event, but in general they do not dramatically change the estimated impact levels due to refugee populations. At four of five fault locations, median fatality estimates reach over 100 fatalities for earthquakes above magnitude 6.4. Accordingly, refugee populations are sufficiently large to produce fatality estimates that would require local or regional response. On the Kırıkhan fault, refugee population fatalities are high enough to merit international response. Thus, it is clear that refugee populations in southeastern Turkey should be included in the fatality estimation process.

However, in comparison to baseline fatality estimates, refugee populations constitute relatively small portions of overall fatalities. The relative contributions of refugee and non-refugee populations for each scenario are compared in Fig. 6 . The Kırikhan fault scenarios have the highest refugee contributions, with $25-27 \%$ of total scenario fatalities coming from refugee populations. The Göksun, Bozova, and Türkoğlu scenarios all have 7-9\% refugee fatalities, and the Pütürge scenario has only $1-2 \%$ refugee fatalities. These dif- 
Table 5. Median fatality estimates for refugee populations.

\begin{tabular}{lrrrrr}
\hline Fault & $M_{\mathrm{W}}$ & Median fatalities (day) & Median fatalities (night) & MAD $^{*}$ (Day) & MAD* (Night) \\
\hline Pütürge & 5.8 & 0 & 0 & 0 & 0 \\
& 6.4 & 2 & 2 & 1 & 1 \\
& 7.0 & 4 & 5 & 1 & 1 \\
\hline \multirow{2}{*}{ Türkoğlu } & 5.8 & 39 & 52 & 18 & 18 \\
& 6.4 & 83 & 108 & 35 & 33 \\
& 7.0 & 134 & 172 & 53 & 52 \\
\hline \multirow{2}{*}{ Kırıkhan } & 5.8 & 354 & 466 & 193 & 190 \\
& 6.4 & 774 & 987 & 360 & 350 \\
& 7.0 & 1195 & 1519 & 510 & 520 \\
\hline \multirow{2}{*}{ Göksun } & 5.8 & 59 & 168 & 28 & 28 \\
& 6.4 & 131 & 291 & 58 & 56 \\
& 7.0 & 228 & 74 & 97 & 96 \\
\hline Bozova & 5.8 & 55 & 152 & 18 & 19 \\
& 6.4 & 116 & 258 & 36 & 39 \\
& 7.0 & 201 & 65 & 66 \\
\hline
\end{tabular}

* Median absolute deviation
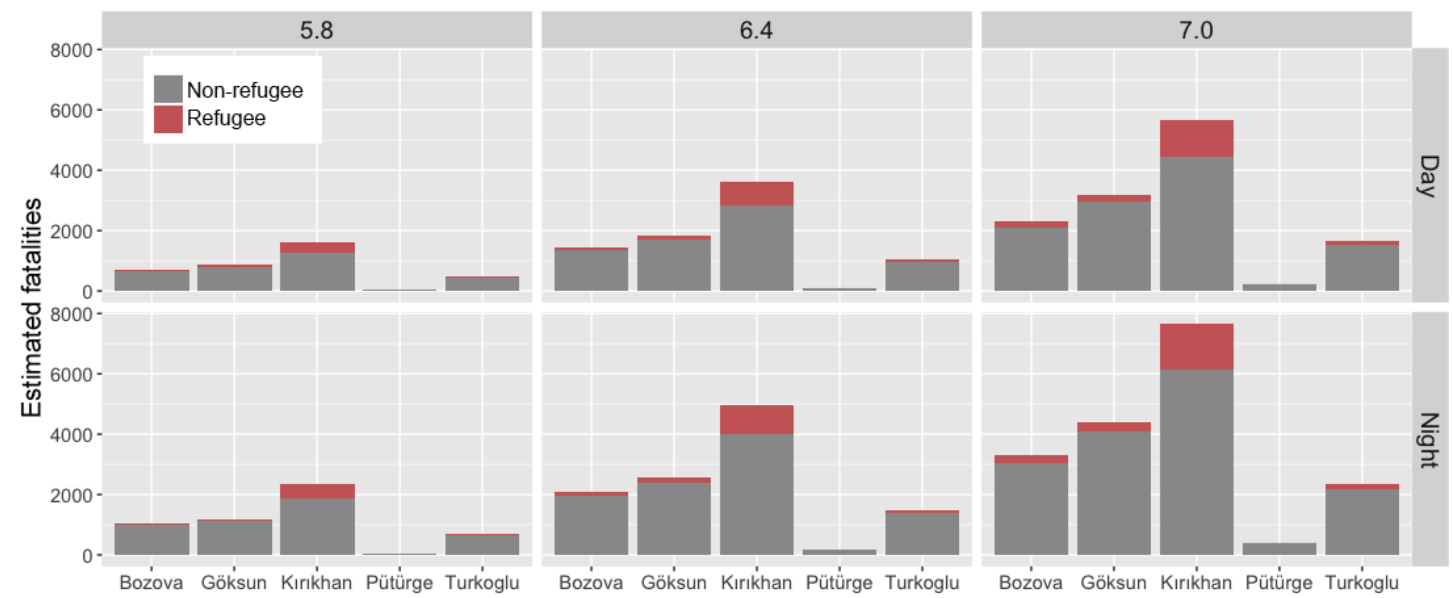

Fault name

Figure 6. Refugee and non-refugee contributions to total estimated fatalities across all earthquake scenarios. Estimated fatalities are separated by time of day and earthquake magnitude.

ferences reflect the distribution of refugees throughout the study region, which is similar but not identical to existing population distributions. As a result, refugee contributions to total fatality estimates are not tied to baseline fatalities. The relationship is fairly close for the scenarios in this study, but as a general rule, baseline fatality estimates should not be assumed to be good predictors of refugee fatality estimates.

\subsection{Uncertainty in semi-empirical methods}

Ground motion, population estimates, collapse rates, fatality rates, and occupancy patterns are all subject to varying levels of uncertainty in the semi-empirical model. In the context of this study, two particular sources of uncertainty are worth highlighting.

1. When compared across all countries, WHE collapse functions have shown tendencies towards overestimating fatalities, with more significant effects in smaller earthquakes (Porter et al., 2008).

2. There are issues with the use of empirical occupancy percentages. Specifically, transit periods are not included, and the outdoor population percentages are not accounted for.

A general shortcoming of fatality estimation processes is the difficulty in separating out individual uncertainty terms. 
As a result, uncertainties are often wrapped together into a total-model-uncertainty term (Jaiswal et al., 2009). The USGS PAGER implementation of total model uncertainty specifies the probability $P$ of estimated losses $e$ falling between two thresholds $a$ and $b$ as Eq. (3).

$$
\begin{aligned}
P(a<e<=b) & =\Phi\left[\frac{\log (b)-\log (e)}{\zeta}\right] \\
& -\Phi\left[\frac{\log (a)-\log (e)}{\zeta}\right]
\end{aligned}
$$

This implementation relies on a hindcasted countryspecific residual error term, $\zeta$, defined as the normalized standard deviation of the logarithmic ratio of expected to recorded losses (Jaiswal et al., 2009).

Because fatality estimations are generally considered to be order-of-magnitude estimates, $a$ and $b$ are commonly set to 1 order of magnitude above and below median estimated fatalities (Jaiswal et al., 2009). Using the $\zeta$ value for Turkey (1.52), the probability $\mathrm{P}$ of actual fatalities in a given scenario falling within 1 order of magnitude above and below median estimated fatalities is $49 \%$. Thus, there is a $25.5 \%$ chance that actual fatalities are greater than 1 order of magnitude above median estimated values and a $25.5 \%$ chance that actual fatalities are less than 1 order of magnitude below median estimate values. These relationships apply to every scenario in this study.

\section{Conclusions}

This study assessed the impact of Syrian refugee migration on earthquake fatality estimations in southeastern Turkey using a semi-empirical loss estimation technique on minimally modeled gridded population datasets created from refugee statistics and Turkish ABPRS district level population data. It was shown that refugee populations in southeastern Turkey are sufficiently large to produce fatality estimates requiring local or national relief - fatalities on the order of tens to 2000 individuals, varying with location and earthquake magnitude. Refugee fatality estimates were then compared to non-refugee fatality estimates, showing that the relative contribution of refugee populations to total estimated fatalities ranges from 1 to $27 \%$. While it naturally follows that migration resulting in increased populations results in additional estimated fatalities for earthquake events, it had not yet been determined to what degree current refugee levels would contribute to total fatality estimates.
Because of data limitations, this study incorporated refugees into earthquake fatality estimations with large uncertainties. This creates a number of follow-up research opportunities. Dedicated studies investigating the structural conditions, spatial distribution, or migration patterns of refugee populations, among other topics, would improve the efficacy of earthquake risk assessment in countries with high refugee populations. Further work characterizing the vulnerability of refugees is also an important future step in understanding how their presence influences earthquake risk assessments.

Characterizing the expected fatality increases related to refugee populations is an important step in loss estimation methodologies. Underestimations of disaster scale have the potential to complicate the work of local governments and aid agencies working to respond to earthquake disasters (Jaiswal et al., 2011b). The results of this study help to characterize the scale of potential fatality underestimations in southeastern Turkey and communicate the greater importance of placing natural-hazard studies in an appropriate regional context. This study also provided a methodology for making contextual population adjustments in places where census data remain the de facto standard for environmentalhazard studies. These types of approaches will only become more relevant as more refugees flee from the conflict in Syria into southeast Turkey.

Data availability. The population models used in this project were constructed with freely available and frequently updated data from the Address Based Population Registration System (Turkish Statistical Institute, 2015) and the Turkish Ministry of Interior Directorate General of Migration Management (Republic of Turkey, 2015). The Global Earthquake Model's OpenQuake platform was used to produce all earthquake simulations (GEM, 2016) in this study. The source models used as the basis for these simulations are available from the SHARE initiative (Giardini et al., 2013). Site amplification data used in scenario creation are available from the US Geological Survey's global Vs30 grid (US Geological Survey, 2013), described in Wald and Allen (2007). Building occupancy and collapse rate data from the WHE-PAGER phase I survey are published in Jaiswal and Wald (2009b). Please contact the corresponding author for the $\mathrm{R}$ loss estimation code or GIS processing workflows. 


\section{Appendix A}

The process for determining fragility coefficients is described at length in Jaiswal et al. (2011a), with selected building types presented. A more complete list of coefficients was presented at the summer 2009 WHE-PAGER workshop (Jaiswal and Wald, 2009a).

Table A1. Fragility coefficients.

\begin{tabular}{lrrrr}
\hline WHE-PAGER type & $\mathrm{A}$ & $\mathrm{B}$ & $\mathrm{C}$ & $R^{2}$ \\
\hline $\mathrm{DS}$ & 9.52 & -4.89 & 5.32 & 0.95 \\
$\mathrm{~A}$ & 10.76 & -5.34 & 4.05 & 0.91 \\
UFB & 3.88 & -4.22 & 4.97 & 0.94 \\
UCB & 2.15 & -5.18 & 5.11 & 0.95 \\
C2 & 1.95 & -6.14 & 5.90 & 0.89 \\
C3 & 3.42 & -5.03 & 5.62 & 0.93 \\
C6 & 2.55 & -5.03 & 4.91 & - \\
C7 & 1.94 & -1.91 & 5.99 & - \\
PC2 & 0.85 & -2.35 & 5.90 & 0.95 \\
S1 & 0.45 & -8.71 & 4.40 & 0.80 \\
W6 & 1.14 & -2.66 & 5.49 & - \\
\hline
\end{tabular}

$R^{2}$ denotes uncertainty compared to building performance records. Asterisks indicate building types with fragility coefficients calculated from a single expert estimate. 
Competing interests. The authors declare that they have no conflict of interest.

Acknowledgements. We appreciate the constructive feedback provided by reviewers on earlier versions of this paper. This research was performed under a National Science Foundation Graduate Research Fellowship, grant no. DGE-1450079. We also thank the University of Arkansas for additional research support.

Edited by: Filippos Vallianatos

Reviewed by: two anonymous referees

\section{References}

3RP: Regional Refugee \& Resilience Plan 2015-2016, Tech. rep., United Nations Development Programme, 2015.

Akkar, S. and Bommer, J. J.: Empirical equations for the prediction of PGA, PGV, and spectral acceleration in Europe, the Mediterranean Region, and the Middle East, Seismol. Res. Lett., 81, 195-206, https://doi.org/10.1785/gssrl.81.2.195, 2010.

Ambraseys, N.: Temporary seismic quiescence: SE Turkey, Geophys. J. Int., 96, 311-331, https://doi.org/10.1111/j.1365246X.1989.tb04453.x, 1989.

Ambraseys, N.: Earthquakes in the Mediterranean and Middle East: A multidisciplinary study of seismicity up to 1900 , Cambridge, 2009.

Anbarci, N., Escaleras, M., and Register, C. A.: Earthquake fatalities: the interaction of nature and political economy, J. Public Econ., 89, 1907-1933, 2005.

Ara, S.: Impact of temporal population distribution on earthquake loss estimation: A case study on Sylhet, Bangladesh, Int. J. Disast. Risk Sc., 5, 296-312, https://doi.org/10.1007/s13753-0140033-2, 2014.

Aubrecht, C., Freire, S., Neuhold, C., Curtis, A., and Steinnocher, $\mathrm{K}$.: Introducing a temporal component in spatial vulnerability analysis, Disaster Adv., 5, 48-54, 2012.

Barka, A. A. and Kadinsky-Cade, K.: Strike-slip fault geometry in Turkey and its influence on earthquake activity, Tectonics, 7, 663-684, https://doi.org/10.1029/TC007i003p00663, 1988.

Chen, K., McAneney, J., Blong, R., Leigh, R., Hunter, L., and Magill, C.: Defining area at risk and its effect in catastrophe loss estimation: a dasymetric mapping approach, Appl. Geogr., 24, 97111, https://doi.org/10.1016/j.apgeog.2004.03.005, 2004.

Chen, R., Jaiswal, K. S., Bausch, D., Seligson, H., and Wills, C.: Annualized earthquake loss estimates for California and their sensitivity to site amplification, Seismol. Res. Lett., 87, 13631372, https://doi.org/10.1785/0220160099, 2016.

Chorowicz, J., Luxey, P., Lyberis, N., Carvalho, J., Parrot, J., Yürür, T., and Gündogdu, N.: The Maras Triple Junction (southern Turkey) based on digital elevation model and satellite imagery interpretation, J. Geophys. Res., 99, 225-242, https://doi.org/10.1029/94JB00321, 1994.

Coburn, A. and Spence, R.: Earthquake Protection, 2nd Edn., John Wiley, Hoboken, New Jersey, 2002.

Çorabatır, M.: The evolving approach to refugee protection in Turkey: Assessing the practical and political needs, Report, Migration Policy Institute, Washington, D.C., 2016.
Doxsey-Whitfield, E., MacManus, K., Adamo, S. B., Pistolesi, L., Squires, J., Borkovska, O., and Baptista, S. R.: Taking advantage of the improved availability of census data: A first look at the Gridded Population of the World, Version 4, Appl. Geogr., 1, 226-234, https://doi.org/10.1080/23754931.2015.1014272, 2015.

Duman, T. Y. and Emre, O.: The East Anatolian Fault: geometry, segmentation and jog characteristics, Geological Society London Special Publications, 372, 495-529, https://doi.org/10.1144/SP372.14, 2013.

EERI: Scenario for a magnitude 7.0 earthquake on the Wasatch Fault-Salt Lake City segment: hazard and loss estimates, Report, Earthquake Engineering Research Institute, Salt Lake City, Utah, 2015.

Erdik, M.: Report on 1999 Kocaeli and Düzce (Turkey) earthquakes, in: Structural control for civil and infrastructure engineering, edited by: Casciati, F. and Magonette, G., 149-186, World Scientific, 2001.

Erdik, M., Sestyan, K., Demircioglu, M. B., Hancilar, U., and Zulfikar, C.: Rapid Earthquake Loss Assessment After Damaging Earthquakes, Vol. 17 of Geotechnical, Geological, and Earthquake Engineering, chap. 21, 523-547, Springer, https://doi.org/10.1007/978-90-481-9544-2_21, 2011.

FEMA: HAZUS-MH estimated annualized earthquake losses for the United States, Open file report 366, Federal Emergency Management Agency, Washington, D.C., 2008.

Freire, S. and Aubrecht, C.: Integrating population dynamics into mapping human exposure to seismic hazard, Nat. Hazards Earth Syst. Sci., 12, 3533-3543, https://doi.org/10.5194/nhess12-3533-2012, 2012.

GAA (Global Administrative Areas): GADM database of global administrative areas, version 2.6, available at: http://www.gadm.org (last access: January 2017), 2015.

Garfunkel, Z., Zak, I., and Fruend, R.: Active faulting in the Dead Sea Rift, Seismol. Res. Lett., 80, 1-26, https://doi.org/10.1016/0040-1951(81)90139-6, 1981.

GEM: The OpenQuake-engine User Manual, Technical report 2016-03, The Global Earthquake Model, doi:10.13117/GEM.OPENQUAKE.MAN.ENGINE.1.9/01, 2016.

Giardini, D., Woessner, J., Danciu, L., Crowley, H., Cotton, F., Grünthal, G., Pinho, R., Valensise, G., Akkar, S., Arvidsson, R., Basili, R., Cameelbeeck, T., Campos-Costa, A., Douglas, J., Demircioglu, M., Erdik, M., Fonseca, J., Glavotovic, B., Lindholm, C., Makropoulos, K., Meletti, C., Musson, R., Pitilakis, K., Sesetyan, K., Stromeyer, D., Stucchi, M., and Rovida, A.: Seismic Hazard Harmonization in Europe (SHARE): Online Data Resource, https://doi.org/10.12686/SED-00000001SHARE, 2013.

Guha-Sapir, D. and Vos, F.: Human Casualties in Earthquakes, Vol. 29 of Advances in Natural and Technological Hazards Research, chap. 2, 13-24, Springer, https://doi.org/10.1007/978-90481-9455-1, 2011.

Güney, D.: Van earthquakes (23 October 2011 and 9 November 2011) and performance of masonry and adobe structures, Nat. Hazards Earth Syst. Sci., 12, 3337-3342, https://doi.org/10.5194/nhess-12-3337-2012, 2012.

Ilki, A. and Celep, Z.: Earthquakes, existing buildings and seismic design codes in Turkey, Arab Journal of Science and Engi- 
neering, 37, 365-380, https://doi.org/10.1007/s13369-012-0183$8,2012$.

Jaiswal, K. and Wald, D.: Summary of the WHE-PAGER survey (Phase I, II \& III), EERI Meeting, Golden, CO, 23 September 2009, available at: http://www.world-housing.net/wp-content/ uploads/pager/2009/09/Jaiswal-EERI-Meeting-Sept-23-2009_ WHE-PAGER-Survey.pdf (last access: October 2017), 2009a.

Jaiswal, K. and Wald, D. J.: Analysis of collapse fragilities of global construction types obtained during the WHE-PAGER Phase I Survey, Survey report, WHE and USGS, Golden, Colorado, 2009b.

Jaiswal, K. and Wald, D.: Development of a semi-empirical loss model within the USGS Prompt Assessment of Global Earthquakes for Response (PAGER) System, in: Proceedings of the 9th US and 10th Canadian Conference on Earthquake Engineering: Reaching Beyond Borders, Toronto, Canada, 2010.

Jaiswal, K., Wald, D. J., and Hearne, M.: Estimating Casualties for Large Earthquakes Worldwide Using an Empirical Approach, Open File Report 2009-1136, USGS, Reston, Virginia, 2009.

Jaiswal, K., Wald, D., and D'Ayala, D.: Developing empirical collapse fragility functions for global building types, Earthq. Spectra, 27, 775-795, https://doi.org/10.1193/1.3606398, 2011a.

Jaiswal, K., Wald, D., Earle, P., Porter, K., and Hearne, M.: Earthquake casualty models within the USGS Prompt Assessment of Global Earthquakes for Response (PAGER) System, Vol. 29, 8394, Springer Netherlands, $2011 \mathrm{~b}$.

Keefer, P., Neumayer, E., and Plümper, T.: Earthquake propensity and the politics of mortality prevention, World Dev., 39, 15301541, https://doi.org/10.1596/1813-9450-5182, 2011.

Meghraoui, M., Gomez, F., Sbeinati, R., der Woerd, J. V., Mouty, M., Darkal, A. N., Radwan, Y., Layyous, I., Najjar, H. A., Darawcheh, R., Hijazi, F., Al-Ghazzi, R., and Barazangi, M.: Evidence for 830 years of seismic quiescence from palaeoseismology, archaeoseismology and historical seismicity along the Dead Sea fault in Syria, Earth Planet. Sc. Lett., 210, 35-52, https://doi.org/10.1016/S0012-821X(03)00144-4, 2003.

Musson, R.: The ten deadliest ever earthquakes, available at: http://www.earthquakes.bgs.ac.uk/archive/archive_collections/ Deadly.html (last access: 15 November 2016), 2001.

Nadim, F., Moghtaderi-Zadeh, M., Lindholm, C., Andresen, A., Remseth, S., Bolourchi, M. J., Mokhtari, M., and Tvedt, E.: The Bam earthquake of 26 December 2003, B. Earthq. Eng., 2, 119 153, https://doi.org/10.1007/s10518-004-2286-4, 2004.

ORNL (Oak Ridge National Laboratory): Landscan ${ }^{\mathrm{TM}}$, available at: http://web.ornl.gov/sci/landscan/ (last access: January 2017), 2016.

OECD: Creating rural indicators for shaping territorial policy, Tech. rep., OECD Publications, Paris, France, 1994.

Oskai, Y. and Minowa, M.: Factors associated with earthquake deaths in the great Hanshin-Awaji earthquake, 1995, Am. J. Epidemiol., 153, 153-156, https://doi.org/10.1093/aje/153.2.153, 2001.

Over, S., Ş. Kavak, K., Bellier, O., and Özden, S.: Is the Amik Basin (SE Turkey) a triple-junction area? Analyses of SPOT XS imagery and seismicity, Int. J. Remote Sens., 25, 3857-3872, https://doi.org/10.1080/01431160310001654437, 2004.

Perinçek, D. and Çemen, İ.: The structural relationship between the East Anatolian and Dead Sea fault zones in southeastern Turkey,
Tectonophysics, 172, 331-340, https://doi.org/10.1016/00401951(90)90039-B, 1990.

Porter, K., Jaiswal, K., Wald, D., Earle, P., and Hearne, M.: Fatality models for the U.S. Geological Survey's Prompt Assessment of Global Earthquakes for Response (PAGER) System, in: Proceedings of the 14th World Conference on Earthquake Engineering, Beijing, China, 2008.

Republic of Turkey: Migration Statistics: Temporary Protection, available at: http://www.goc.gov.tr/icerik3/ temporary-protection_915_1024_4748 (last access: 15 January 2017), 2015.

Sbeinati, M. R., Darawcheh, R., and Mouty, M.: The historical earthquakes of Syria: an analysis of large and moderate earthquakes from 1365 B.C. to 1900 A.D., Ann. Geophys., 48, 347435, https://doi.org/10.4401/ag-3206, 2005.

Sesetyan, K., Demircioglu, M., Rovida, A., Albini, P., and Stucchi, M.: SHARE-CET, the SHARE earthquake catalogue for Central and Eastern Turkey complementing the SHARE European Earthquake Catalogue (SHEEC), available at: http://www. emidius.eu/SHEEC/docs/SHARE_CET.pdf (last access: 15 December 2016), 2013.

Turkish Statistical Institute: Central Dissemination System, available at: https://biruni.tuik.gov.tr/medas/?kn=95\&locale=en (last access: 15 January 2017), 2015.

US Geological Survey: Global Vs30 Map Server, available at: http: //earthquake.usgs.gov/hazards/apps/vs30/ (last access: 15 January 2017), 2013.

van Stiphout, T., Wiemer, S., and Marzocchi, W.: Are short-term evacuations warranted? Case of the 2009 L'Aquila earthquake, Geophyis. Res. Lett., 37, L06306, https://doi.org/10.1029/2009GL042352, 2010.

Wald, D. and Allen, T.: Topographic slope as a proxy for seismic site conditions and amplification, B. Seismol. Soc. Am., 97, 1379-1395, https://doi.org/10.1785/0120060267, 2007.

Wald, D. J., Quitoriano, V., Heaton, T. H., and Kanamori, H.: Relationships between peak ground acceleration, peak ground velocity, and Modified Mercalli Intensity in California, Earthq. Spectra, 15, 557-564, https://doi.org/10.1193/1.1586058, 1999.

Wells, D. L. and Coppersmith, K. J.: New empirical relationships among magnitude, rupture length, rupture width, rupture area, and surface displacement, B. Seismol. Soc. Am., 84, 974-1002, 1994.

Woessner, J., Laurentiu, D., Giardini, D., Crowley, H., Cotton, F., Grünthal, G., Valensise, G., Arvidsson, R., Basili, R., Demircioglu, M. B., Hiemer, S., Meletti, C., Musson, R. W., Rovida, A. N., Sesetyan, K., Stucchi, M., and The SHARE Consortium: The 2013 European Seismic Hazard Model: key components and results, B. Earthq. Eng., 13, 3553-3596, https://doi.org/10.1007/s10518-015-9795-1, 2015.

Wyss, M.: Earthquake loss estimates in real time begin to assist rescue teams worldwide, EOS, 85, 565-570, https://doi.org/10.1029/2004EO520001, 2004.

Zare, M., Amini, H., Yazdi, P., Sesetyan, K., Demircioglu, M. B., Kalafat, D., Erdik, M., Giardini, D., Khan, M. A., and Tsereteli, N.: Recent developments of the Middle East catalog, J. Seismol., 18, 749-772, https://doi.org/10.1007/s10950-014-9444-1, 2014. 